\title{
内科診療の進歩 (抄録)
}

\author{
1. 貧血一赤血球フェリチンを中心にしてー \\ 北海道大学医学部第三内科 宮㠃 保
}

䝱血は臨床の場にあって高血圧, 消化性潰瘍, 糖尿 と並んでよくみられる症状である，従って，貧血の診 断, 病態把握, 予後判定拈よび治療方針の決定などの ために有用な指標が数多くある。しかし，その基本は， 簡便かつ迅速，信頼性が高く，高価でないことなどが 条件となる。

赤血球フェリチンについて述べる前に, 血清フェリ チンについてふれる，血清フェリチンは今でこそRIA 法などにより容易に測定されているが，長年月の研究 の上に完成したものである。しかし，血清フェリチン にはその個体の肝障害, 感染・炎症, 悪性腫瘍の存在, 出血, 輸血などが複雑に影響することが明らかにされ ている.

その点, 赤血球フェリチンはそれらの影響が少なく，
生体の鉄代謝状態，造赤血球状態を反映するところが 大であり，負血の診断などの面でその意義も高いと考 克ら机る。しかし, 国内, 国外共にこの分野の研究は それ程なされていないの事実である。

以下に，筫血齐示寸鉄欠之性筫血，再生不良性筫血， 溶血性負血, 墨性負血, MDS (Myelodysplastic syndrome：骨䯣異形成症候群), 続発性貧血などについて 赤血球フェリチン量, 赤血球フェリチンの多様性（等 電点電気泳動による検討),フェリチンサブニニットを してのL-，H-からの検討，分子レベルからの検討など の結果を述べる. 赤血球フェリチンは造血状態, 体内 の鉄動態のみならずL-，H・サブニニットの測定の有用 性が明らかとなり，賽血の診断などに㧊いてをの意義 は極めて高い。

\section{2. 二次性高血圧症の診断と治療一最近の進歩一}

\section{東北大学医学部第二内科 阿部圭志}

現在日本には約 2000 万人の高血圧患者がいるが，そ の10１5\%は原因疾患のあるいわゆる二次性高血圧症 あるいは症候性高血王症である。二次性高血王症の中 には外科的治療などにより根治可能なものがありその 診断は重要である。近年, 高血圧症の診断と治療に関 して長足の進歩がみられ，根治可能な高血圧症につい てもその様相が一変している. 代表的な症候性高血圧 症の原発性アルドステロン症(アルドステロン産生腺 腫), Cushing症候群, 褐色細胞腫, 腎血管性高血正症 の診断と治療に関する最近の進歩について述べる.1) フルドステロン産生腺腫：内分泌学的検査や画像診断 の進歩に伴い, 診断之腫場の局在診断が容易となった。 自験150例中両側に腫痬が確認された症例が 3 例あり, 術前には特発性アルドステロン症との鑑别が困難であ り, 術後の腺腫と周辺組織におけるステロイド合成酵
素 ( $3 \beta-\mathrm{HSD}$ と $\left.450_{\mathrm{c} 11}\right)$ の免疫組織検查にて診断が確 定された。また，腺腫にも多様性があり，アルドステ ロンと同時に自律性コルチゾール分泌を伴った症例を 4 例認めた。こ机らでは腫瘍組織に充実型細胞が混在 し, 免疫組織学的にP $450_{17 \alpha}$ が陽性であり, 術後にステ ロイド補充が必要であった。治㞠法として腹腔鏡下副 腎摘出術む導入され，手術侵襲は軽減している。また， 術前や非手術例では脳・心血管合併症がまれではない。 2) Cushing症候群：92例を経験したが，副腎腺腫例上 下垂体性疾患の診断が容易上なった。ダイナミック MRIにより下垂体微小腺腫の診断も可能となった。下 垂体疾患の手術不成功例では $\boldsymbol{\gamma}$-ナイフ治療を行ってい る. 原発性両側性副腎皮質結節性過形成の 4 例では定 型的な䧗床症候が認められなかった。低機能性のpre・ Cushing症候群症例も增加している．3）褐色細胞腫： 
副腎性72例，副腎外性19例で，家族性は 6 家系13例( ちSipple症候群が 5 家系10例)を認めた。 CT, MRI, ${ }^{131}$ I-MIBGシンチグラフィーなどの導入により腫瑒の部 位診断が容易になった。悪性畽煌例ではCVD (cyclophosphamide, vincristine, dacarbazine)療法 を試みている、4）督血管性高血圧症：カプトプリル試 験がスクリーニングに有用で, 確定診断にはDSA(dig- ital subtraction angiography）が用いられている。診 断法の進歩により腎動脈分枝狭窄例が多数発見される 上5になった，治療には経皮的管腔内血管拡張術が導 入され，外科的手術例，特に腎摘出術が減少した。変 换酵素阻害薬, $\beta$ 遮断薬, Ca拮抗薬などの降王薬が用い られて内科的療法を行う症例も増えてきている。

\section{3. 心臓性突然死の実態之機序}

\section{聖マリアンナ医科大学第二内科 村山正博}

突然死のWHO定義は「予想せざる発症から24時間 以内」の死亡となっているが，その捉方方は疫学，法 医学，臨床それぞれの立場によって同一ではない，心 臓性突然死は症状が発現してから 1 時間以内の死亡と 取る人が多く，また米国では放置すれば死亡に至った であるうニヤミス例も突然死に入れている。従って， 心臓性突然死の実態と機序の検討には，その目的に 沿った対象の選択が重要となる。

先ず，実態として重要なのは一般社会人に批ける突 然死であるが，本邦では河合らが京都市で行った調查 は 82 人/10万・年の頻度を報告して叔り，これは全国的 に怙よそ9.8万人/年の数字になる。我々が東京都で調 查した健康人に打斿突然死の特改は，(1) 男性に多 く，（2）加齢に伴い增加，（3）死亡発生時の状況は睡


身支度の順であったが，単位時間当りに換算した危険 率の高いのは40〜59歳ではスポーッ，排便，入浴，60 歳以上では入浴, 排便。（4）剖検からみた基礎疾患と
しては虚血性心疾患がもっとも多かった，健康者に招 ける突然死にはいかゆる過労死が社会的に大きな関心 を集めているが，医学的実態及び機序については不明 の点が多い.

疲学的研究は突然死の実態把握には重要であるが, 機序解明には限界がある。皇こで臨床的立場からCCU などの救命施設におけるDOAちるいは急性疾患に関 連した突然死の実態，または疾㶳を有する人の慢性期 に抢ける日常生活中における突然死例個々の詳細な観 察から機序の推定が行われている，そのためと各種心 疾患に㧊いてHolter心電図，電気生理学的検查などを 用いた突然死機序解明のための研究が進行中であり， 特に心筋梗塞，心筋症など基礎疾患を背景とした致死 性不整脈见よる機序及び予知の方法汇関する研究が盛 んである，最近これらの基礎疾患が明らかでない特 発性心室細動が注目されているが，機序解明に関する 研究は始まったばかりである。

\section{4. 呼吸不全と呼吸筋疲労}

\section{横浜市立大学医学部第一内科 大久保隆男}

呼吸不全は厚生省の特定疾患研究班の一つ之して取 り上げられ，保険医療に打いても近年その対策として 在宅酸素吸入療法が導入された。呼吸不全は呼吸器疾 患の重要かつ重篤な病態の一つであり，患者の生活の 範囲や質を規定する因子としての社会的問題も大き $\downarrow$.

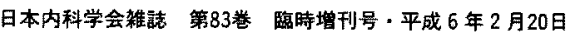

呼吸不全は，肺胞内に括けるガス交換障害を主体と する肺不全型と，胸郭運動の障害に上り空気の出入り が傷害されるポンプ不全型に大別される，前者につい ては従来より多くの検討がなされており，在宅酸素療 法の適応も主として肺不全型である、一方, 以前は呼 吸筋は疲労しないと云われ, ポソプ不全は神経筋疾患 
や胸郭変形の患者で注目されているに過ぎなかった。 しかしながら, Rousoss \& Macklem (1977) の研究 以来，ポンプ不全に基らく呼吸不全は，特に呼吸筋疲 労との関連で注目されるょらになった。また一力，換 気に打ける肺胸郭系の機械抵抗の增大子呼吸困難感の 発生との関連が重視されており，この点から女呼吸筋 疲労は重大な意味を持つ。

さらに従来, 呼吸筋疲労の研究は主な吸気筋である 横隔膜を中心になされて来た。しかしながら慢性呼吸 不全の主たる原因疾患である閉塞性肺疾患の重要な病 態は呼気閉塞であり，そのために呼気時の抵抗は著し
く増大する，さらに，呼気筋は正常の換気運動では使 われることが少ないため，病的な使用に上り容易に疲 労に落ちいるものと推定される。私どもはこのような 理由で，従来の呼吸筋疲労による呼吸不全の考え方に 呼気笳疲労の概念を付加した。実際に肺線維症などの 拘束性障害群の呼吸筇疲労は吸気筋疲労が主であるの に対して，慢性閉塞性肺疾患の呼吸筋疲労の場合は呼 気筋疲労の割合が大きいことを明らかにした。

本講演に打いて私は，呼吸筇疲労の呼吸不全に就け る病態生理学的な意義を述べ，そのメカニズムに基ず いて症状，診断，治療法等を概観する。

\section{Cushing病の内科的治療}

䁌皁大学名举教授

松波総合病院一内分泌・代謝疾患七ンタ一長 三浦 清

Cushing病は，多くの場合，下垂体にACTH座生腺腫 が発生し，これにより，慢性のcortisol過乘分泌が惹起 されるために発症する疾患で，難病中の難病である。 各種の副腎・下垂体外科療法のうち, 最近 transs. phenoidal pituitary microsurgery (Hardy手術) מ゙普 及し，治潦成績は長足に進歩した。しかし一般的には， 宽解率恃必ずしも高くなく, 術挠再発例や術後各種下 垂体機能低下発症例も少なくない，長期follow-up成續 も未だ不明である。一方，内科的療法〔薬物療法（副 腎ステロイド産生・合成阻害剤及びACTH分泌抑制 剂)，又はこれらと下垂体照射（下照）併用療法了の研 究も，峃独で，又性科的療法との組合せで，続けら れ，進歩し，かなりの患者を治せる時代に入った。

本講演では，主な内科的療法の進歩について，特に， ACTH分泌抑制剂ないしはこれと下照併用による療 法の進歩を概説する。後者の概要は以下の様である。

1) Bromocriptine (B : Dopamine agonist) 療法:
1982年Lambertsらにより或種の例で有効之唱えられ， 内外の追試でも，有效な例もあるとされた，自験 7 例 では，各例B 1 日最高17.5 - 25mg投与の 3 例では無效 で, 1 日最高35 55mgの大量投与例 4 例中 3 例で有效 であった，Hardy手術不成功例で，Bと下照併用が有効 との報告 (抄録) もある，2）Cyproheptadine (C: 抗 セロトニン剂) 療法：1975年KriegerらによりCが有益 とされた。しかし，内外で，C単独投与で長期に有効と いう結論には至っていない，3) Reserpine(R)と下照 併用療法：1975年演者らが報告した治療法で, 20例中, 初期寛解例16例，4例で再発， 1 例は他疾患で死亡し たが，残の11例では，1990年までの 2-25年，平均 $15.5 \pm 8.9($ Mean $\pm \mathrm{SD})$ 年のfollow-upで，寛解が持続 した。かつ，筧解例では，各種の下垂体機能が，それ ぞれ半数例で或いは全例で，正常化した，Hardy手術 不成功例でも，追加した本療法が有効といら報告もな された。

\section{6. 骨粗箖症一予防と治療一}

\section{東京大学医学部老年病学教室 折茂 肇}

骨粗髹症の予防及び治療の最终目標は, 骨折の防止 にある、骨折に関連する要因として最も重要なむのは，
骨量の減少であり，骨折の約 $80 \%$ は骨量の減少により 説明できるといわれている，従って，骨量の隇少を防 
止することは骨折を防止する上で極めて重要で，骨量 の測定が䂆防及び治療効果を判定する際の指標として 有用である。

加龄に伴い骨量が減少するが，その減少の程度は人 により様々である。一般に骨量は30－40歲台で最高値 に達し以後減少するが，閉経後の減少の速度が極めて 著明な一群（fast loser）が存在し，かかる群が将来閉 経後骨粗矮症になる可能性の高い予備群と考えられ 名。

次に最高值が初めから低值を示す一群があり，かか る群も将来骨粗婑症になる可能性の高い予備群之考之 られる、従ってこの様な群を早期に発見し予防するこ とが極めて重要である。骨量が著しい低值を示し，か つ骨折を起こした症例ではその治療は困難となるので 本症の予備群老速やかに発見し予防的治療定行 らこと
が今後の課題である。次に問題となるのは，いわゆる， 確実な骨粗䯱症の治療はどらしたら良いかという点で ある。

本症学代謝の障害，すなわち骨吸收之骨形成のun couplingにより発症し，一般に骨代謝の面からは高代 竧回転型と低代謝回転型の二つの病型が存在すると考 えられている。

本症を骨の代謝の面からこのような二つの病型に分 けることは治療方針を決める際にきわめて重要であ る、すなわち，高代謝回転型では骨吸収え進を抑制す ることが重要であり，そのために骨吸収抑制作用を有 する薬物を主として用い，一方，低代謝回転型では骨 形成の低下を改善することが必要で骨の代謝回転を刺 激して骨形成を促進させる作用のある薬物を用いる。

\section{7. 糖尿病性腎症の治療}

\section{新渴大学医学部第二内科 荒川正昭}

糖尿病性腎症（腎症）の蛋白尿上腎機能障害は，糸 球体，厡細管执よび間質障害の絵合的な結果である。 したがって，腎症の治療は，これらの組織学的な改善 あるいは進展の抑制をもって評価すべきであるが，現 実には蛋白尿と腎機能の変化で評価することが実際的 である．今回，演者は，㹂症治療の現状と問題点につ いて話したい。

1）血糖管理：厳格な血糖管理は，微量アルブミン尿 を減少するかi，顕性堅症の蛋白尿之腎機能低下は抑制 しないと報告されている。しかし，その臨床的意義は どの病期に扣いても重要である。

2）低蛋白食：低蛋白食は，徽量アルブミン尿，腎機 能の進展抑制に有効であるが，効果がないという報告 もある.今後は，開始すべき時期，長期的な效果执よ び栄養学的な問題を検討する必要がある。

3）降圧薬：アンジテンシン変換酵素阻害薬の蛋 白㾁之腎機能への効果について，いろいろ議論されて いるが，蛋白尿は減少与るが，堅機能障害への効果は
少ないという報告が多い、しかし，カルシウム拮抗薬 との比較では，一定の成績はなく，系球体内の血行動 態と関連した薬理作用について，問題点が残されてい 乃。

4）抗血小板薬・トロンボキサン合成阻害萗・プロス タグランジン製剤：糸球体内の凝固能や腎血行動態の 変化を改善し，蛋白尿を減少させるといら報告がある。

5）高脂血症薬：HMG還元酵素阻害薬などの高脂 血症薬が，蛋白尿を減少させるという報告がある，脂 質, 特に，LDL-コレステロールやアポ蛋白と，メサン ギウムあるいは糸球体係蹄の陰性荷電との関連が注目 されている。

6）透析療法：埥症が，我が国の血液透析患者の原疾 患の第 2 位となって久しく，最近では新規導入患者の 約30\%が本症である。慢性系球体腎炎に上る症例と比 較して，透析導入時の病態には様々な相違点があり， 新しい視点にたって検討する必要がある。 


\section{8. アルコール性臓器障害の基礎と臨床}

一肝・消化管障害を中心として一

\section{順天堂大学消化器内科 佐藤信紘}

洋の東西を問わず社会の成熟とともにアルコール関 連疾患は増加し，わが国で数百万，フメリカでは 1000 万を越えるアルコール問題患者がいると推定されてい る. 疾病を含めた社会的損失は計り知れないが，一方 そのbenefit化ついても昨今少しずつ解明されてきた。 アルコールおよびその代謝産物であるアセトアルデ ヒドは，神経・内分泌系さらに免度や大・微小循環系 に多大の影響を与充，糖・脂質・蛋白質代謝や肝での フルコール自身や薬物の代謝を介して中枢神経系や循 環器, 消化器疾患の発症・進展に関与する. さらに, アルコール飲料に含まれる発癌物質, 突然変異能を有 する物質や肝における procaricnogenの活性化によっ
て発癌にる関連することが最近明らかにされてきた。 ここでは, 細胞, 分子, 遗云子レべルで得られた基 磯的研究踏まえて，日常の臨床におけるアルコール の介在, 役割について, 長期間の飲酒が食道, 胃, 小。 大腸，肝藏，膵臓など主として消化器領域の臟器の生 理的機能にいかなる影響を与えこれらの臟器障害と いかに直接的・間接的に関与するか, その特徽的な病 態について述べることにする，とくに，B，C型ウイル ス性肝硬変, 肝癌に和ける领酒の堌悪因子としての役

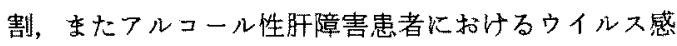
染, とくにHCV感染の役割について最近のトピックス として触れる。

\section{9. ジストニーの症候学とボッリスス治療}

\section{京都大学医学部神経内科 木村 淳}

ジストニーは本来筋トーヌスの異常を意味したが， 見在では全身あるいは局所的な体幹あるいは四肢の不 随意收縮をいう。アテトーゼ，へミバリスムス，コレ ア、チックなど他の不随意運動に比較して持続が長く， 異常な動さとい5より不自然な姿勢の保持として観察 されることが多い，全身性のものには脳性麻痖の他に Wilson病, CO中毒, 脳血管障害があり Jokob Crentzfeldt, Hallervorden Spatz病にもみられることがあ る.

局所性ジストーに好眼瞼痤れん, Meige症候群, 痤 性斜頸, 亚痤があり, 薬物療法, 外科治療, 精神科力 ウンセリングなどがおこなわれているが著効は期待で きない，最近では，対定療法としてボッリスストキシ ン(BTX) が用いられる。この神経毒素は運動神経線 維を含むコリン作動性神経終末に特棵的に結合しアセ チルコリンの放出を制御して筋麻溥をきたす。ボッリ
ヌス菌 (Clostridium Botulinum)が産生する毒素には ヒトのボッリヌス中毒の病原となる $\mathrm{A} ， \mathrm{~B} ， \mathrm{E}$ 含め 8 種類あるが，シストニーの治療としては毒性の最も強 いBotulinum A toxin (BTx) が使用されている.

ボッリヌス治療は，れん縮を示す筋への筋肉内注射 に上って行う. 毒素は注射後30分以内に神経終末に結 合し, 菜理学的な作用は概祙24時間以内に出現する. 効果の発現は 2 - 3 日後であることが多い，毒素が作 用した神経終末への薬理作用は永久的であるが，近傍 のRanvier校輪，終末軸索または神経終板上の軸索分 枝からのsproutingにより，麻疩が回復するため，臨休 効果の持続は平均 2 ～ 4 月である. ボッリヌス治療 の適应疾患は，局所性に不随意な笳収縮を来すデイス トニーすべてを含も. 本治療は対症療法であるので, 原因を問わず，筋れん縮の改善が期待できる。 